individual and the group or nation in which he has his being, and vitally affecting the performance of his function as a free member of a free societyproblems of personal and social hygiene, education, food supply and an innumerable host of others upon which scientific workers have long been engaged and which still engage their thought even amid the preoccupations of war. In the field of the relations of national groups President Roosevelt's Aid-for-Democracies Bill has already paved the way for the lines of future inquiry and research. The vast range of inquiry into the conditions of ultimate security for humanity will draw upon the resources of all sciences, and not upon the biological and social sciences only.

\section{New President of the American Association}

Dr. Irving Langmuir, who has been elected president of the American Association for the Advancement of Science, is a well-known figure in international science, and has interested himself particularly in borderline fields extending between physics and chemistry. Early work by Langmuir on the adsorption and reactions of gases at solid surfaces proved to be of fundamental importance to an understanding of many of the phenomena of colloid chemistry, heterogeneous catalysis, surface tension, and even of such an apparently unrelated subject as thermionic emission. One everyday consequence of this work was the gas-filled electric lamp. Arising out of these investigations came the conception of the orientated monolayer as the state of material at phase boundaries, a view which has led to important advances of our knowledge of the mechanism of lubrication of metal surfaces, and of the structure of oil films on liquid surfaces. In 1938 he visited Great Britain as the first American to deliver the Pilgrim Trust Lecture before the Royal Society when he gave a characteristically informative and fascinating account of his views on the structure of protein films (see Nature, December 17, 1938); and he also delivered the Faraday Lecture of the Chemical Society, when he dealt with monolayers on solids. Dr. Langmuir received the Nobel Prize for chemistry for 1932 and was elected a foreign member of the Royal Society in 1935.

\section{Manchester Literary and Philosophical Society:} Air Raid Damage

Tнe Manchester Literary and Philosophical Society lost its historic home, library and Dalton and Joule memorials in an air raid through the spread of a fire from warehouses. In the eighteenth century, when those who could not subscribe to the articles of the Anglican Church were excluded from the universities, academies were founded in several places, that at Manchester being a specially important one. Among the intellectual leaders of the time were Dr. Thomas Percival, a medical pioneer, and Joseph Priestley; and one of the teachers employed by the academy wás John Dalton. A group meeting at Dr. Percival's house founded the Literary and Philosophical Society in 1781, and it met shortly afterwards for a time in the room attached to the non-subscribing chapel in Cross Street, which has also been burnt out. A little later the Society acquired the fine Georgian house which it has now lost, and, in that house, Dalton did his scientific work. A great deal of his apparatus and many of his notes had been placed in the basement to diminish risks, but the fury of the fire destroyed nearly everything. Dalton's watch, Joule's chronometer, some of Dalton's notes and a few small pieces of apparatus have been found and salved.

The Society has also lost, at least for a time, an income it has long received from a trust established on its behalf. In spite of these misfortunes of war, it is maintaining its activities and is asking the cultural societies of Manchester to take part in a co-operative effort for a common home warthy of the long tradition of scientific leadership associated with the names of Dalton, Joule and many later workers belonging to what is believed to be the next oldest learned society in England after the Royal Society.

\section{The Science Museum : Air Raid Damage}

The Science Museum has suffered damage by bombs during air raids on London. A number of bombs have fallen in the vicinity of the Museum, and although the building has suffered from the loss of windows, little damage has resulted to the collections. In one attack practically all the windows on one side of the building were broken, as well as many of the roof lights. Fortunately, the damage sustained by the Museum collections is slight, although a number of exhibition cases in certain galleries have been damaged by blast. Although the Museum is closed to the public, the Science Library continues to remain open, and to afford the usual facilities to readers and borrowers.

\section{The Respirator in an Emergency}

The Prime Minister and the Lord Privy Seal have both recently referred to the possible use of poison gas by the enemy. Although expressly forbidden at the Geneva Convention signed by all the powers, there are indications that make it highly desirable that the people at large shall take heed of the possibility, and review their individual and personal protection against this most horrible form of attack. Everybody has been provided by the State with an efficient gas mask or respirator; it is a simple matter to see that it is in good order and is instantly available at all times. It is not enough, however, to carry the respirator; the owner should practise frequently taking it out of the case and putting it on, holding his breath in the meantime so that the operation becomes a matter of routine which can be done in a few seconds. The respirator should be worn for periods up to twenty minutes, so that one's behaviour in it becomes perfectly normal and the original nervous feeling is forgotten.

Only after such practice does the respirator become part of oneself, and its wearing a matter of instinct in an emergency. If a person is so unfortunate as to be near a bomb containing a lethal non-persistent 